\title{
Study on Network Mass Incidents from the Perspective of Critical Discourse Analysis
}

\author{
Xinyun Tang \\ Fujian Academy of Social Sciences \\ Fuzhou, China
}

\begin{abstract}
This paper adopts van Dijk's mental theory to investigate the network mass incidents from the perspective of Critical Discourse Analysis. The findings are: new discursive strategies (e.g. special language style and rhetorical devices) utilized by Government Affair Weibo or other big Vs are more acceptable among ordinary netizens, thus promoting the authority and credibility of the government; by comparison, the wide employment of some discursive features (e.g. vagueness) may probably lead to people's misunderstandings of the incidents.
\end{abstract}

Keywords-network mass incidents; critical discourse analysis; Weibo

\section{INTRODUCTION}

In the age of Web 2.0, social media has facilitated the way in which people share information and voice their opinions. In China, due to Twitter being banned under the national legislation, a Chinese microblog called Sina Weibo (hereafter Weibo) was developed. Amongst the microblogs designed by different web portals, Weibo is the largest and most influential social networking site in China (Ong, 2013). According to the fourth quarter statistics in 2018 of Weibo provided by Weibo technique, the number of active monthly users (mau) of Weibo had reached 462 million, which represented an increase of 70 million compared to the corresponding period the previous year ${ }^{1}$.

With the increasingly influential role played by Weibo in society, the Chinese government has placed great emphasis on this new digital platform. A large number of government organizations and officials have their own Weibo accounts, utilizing them as an interactive online platform to collect feedback, release information and serve the public. Consequently, this type of microblog is referred to as a "government affairs Weibo". Due to its immediacy, level of interaction and popularity, government affairs Weibo accounts are the dominant form of government official media on the internet. As such, they assume an important role in knowing and guiding the public opinion in different public affairs, amongst which network mass incidents arouse the great concern.

Mass incidents, in the Chinese context, have similar connotations to social movements or collective action in

\footnotetext{
The statistics are quoted from this

page:
}

western cultures. Network mass incidents, defined by scholars specializing in communication studies, refer to events that attract a high degree of interest from netizens and are widely discussed on the internet. It not only manifests the population's concerns regarding the social problems in the country, but also reflects people's attitudes towards the government and society. Therefore, it is important for the Chinese government to take advantage of government affairs Weibo in order to establish a clean online discussion environment, strengthen its supervision and foster a positive image.

The current studies published by Chinese academics on government affairs Weibo relating to network mass incidents are conducted predominantly from the perspectives of sociology, communications, politics, public policy, public management and public relations. There has been a tendency to focus on communication studies and public relations, spanning the issues of how to utilize and enhance the image of the government through government affairs Weibo, how to utilize government affairs Weibo to refute rumors and how to achieve image restoration in public relations crises. However, there has been inadequate research on the discursive strategies that government affairs Weibo employ in network mass incidents from the perspective of linguistics, which this paper seeks to address. Besides, some big Vs which have large numbers of followers are also taken into consideration because of their great influence on the Internet.

This paper mainly investigates the discourse of government affairs Weibo and We Media in network mass incidents. The supporting materials have been chosen from the posts of influential government affairs Weibo accounts or other influential big Vs on some topics which were the source of debate on Weibo in recent years. Critical discourse analysis (CDA) will be used as the principal approach for data analysis. Furthermore, this study will also discuss the relationship between discourse, power and ideology, thereby exploring how government affairs Weibo, as dominant groups on the internet, use official language to guide the public perception of hot issues.

\section{THEORETICAL BACKGROUND}

Critical Discourse Analysis (henceforth termed CDA) was devised by Roger Fowler in his work, Language and Control (1979), and originates from Critical Linguistics. Unlike traditional methods of discourse analysis, within 
which emphasis is placed on the micro-structure of the syntax or semantics of texts, CDA goes beyond the study of language itself and focuses on the real function of discourse. During the evolution of CDA, Michel Foucault's theory on Discourse and Power, Bourdieu's notion of cultural capital, Antonio Gramsci's and Louis Althusser's notion of cultural hegemony, and Bakhtin's intertextuality were adopted. CDA concerns the study of public discourse, including that in films, newspapers, public speeches, and official documents.

According to H.G. Widdowson (2012, p.70), CDA concerns the broader issues of ideology and social belief in a text. The aim behind CDA is to "reveal to the unwary language user the ideological influences they may be unwittingly subscribing to". In other words, the aim behind CDA is to uncover the hidden ideology behind a discourse and to unveil the relationships among discourse, ideology, and power. Thanks to the pioneering efforts of several leading scholars, there now exist various CDA approaches, such as discursive practice (Fairclough, 1995), the sociocognitive approach (van Dijk, 1983), the discourse historical approach (Wodak and Meyer, 2009), and Foucauldian dispositive analysis (Jäger and Maier, 2006).

As one of the CDA pioneers, van Dijk (2008, p.9) discusses the relationships between discourse and power in his work Discourse and Power, and defines social power in terms of "control... of one group over other groups and their members". If the control violates the interest of group members, it should be seen as the abuse of power. If such control presents in the form of discursive practice, the discourse is used to influence group members, and a complex relationship between discourse and power emerges. Such discourse control amounts to more than social practice, as it changes people's knowledge, ideas, and ideologies. In contemporary society, government organizations, which are perceived as dominant groups, and which have ample social resources in society, utilize their power via discourse control to maintain their dominance (Wang, 1999). As a representative force of the Chinese government on the Internet, the Chinese government affairs website, Weibo, could be considered as one such dominant group online, one that guides public opinion through ideological discourse.

In this paper, van Dijk's mental model (1998) is used to identify the discursive strategies that the government affairs website, Weibo, employs during severe accidents. According to van Dijk, dominant groups employ ideological discourse by employing certain expressions in terms of meaning, structure, syntax, form of the language, rhetorical devices, and interaction. Such ideological discourse (van Dijk, 2000, p. 44-60) is evident in topics, the level of description, the degree of detail, presuppositions, local coherence, contrast, examples, modality, and vagueness. Dominant groups tend to re-define social events by unconsciously influencing the public social cognition, knowledge, beliefs, attitudes, and behavior.

What should be noted is that although Weibo has strict rules on the length of every post (a maximum of 140 characters), Weibo users are allowed to use other semiotic resources (such as hyperlinks, pictures, videos, and emoticons) or Weibo-enabled functions (including re-posts, commentaries, different user names and subjects) to complement verbal texts. Since those comprise a substantial proportion of Weibo discourse, they will be discussed alongside verbal texts.

\section{EMPIRICAL FOUNDATION AND DATA COLLECTION}

This paper is an examination of discourses on mass incidents in recent years on the website. Currently, mass incidents have included natural disasters, traffic accidents, environmental pollution, charity events, violent crimes and social conflicts (Sui and Miao, 2015). Baidu Search Rankings was referred to during the collection of key information on specific issues in these fields. The Sina Weibo platform was chosen in this study due to its great influence in Chinese society.

An advanced search was performed on the website. The terms, "秩序" (order), "私生饭" (celebrity stalker), "毕业" (graduation), "天台" (large roof), and "事故" (accident) were entered as key phrases, and 121 posts produced by Weibo users appeared in the search results.

Posts, under which there were fewer than 100 comments and fewer than 150 re-posts, or which contained irrelevant information, were excluded from this study. A total of 23 posts were therefore chosen for this paper, 4 of which are selected and analyzed in detail below.

\section{DATA ANALYSIS}

E.g. 1: 5 月 10 日上午, 在少数不法分子的煽动和蛊惑下，余杭 中泰及附近地区人员发生了规模性聚集，封堵 02 省道和杭徽高速公 路, 一度造成交通中断, 并有不法分子趁机打砸车辆, 围攻欧打执法 管理人员和无幸群众。有多名民警辅警群众不同程度受伤，数量警车 和社会车辆被掀翻。公安民警在处置过程中始终保持克制。以劝说和 疏通为主, 全力维护秩序。( On the morning of May 10, with the incitement of a few lawbreakers, some people in Yuhang District gathered on a large scale, which cut off the traffic in road No.2 and Huahui Highway. Some lawbreakers pounded against the vehicles, and hit the law enforcement officers and innocent people. Many policemen and assistant policemen were wounded inordinately, and some patro cars and other vehicles were damaged. The policemen showed restraint in handling this issue, and tried their best to keep everything in order.)

In example 1 , it is evident that vagueness of discourse has been adopted to a large extent. In reference to the number of "lawbreakers", the expression "a few" is used instead of a precise number; and the phrase "on a large scale" is used instead of a whole number (of people); the adjective "many" is used in reference to the "policemen and assistant policemen"; and it is mentioned that "some" patrol cars were damaged, and so real data is avoided once again. It is interesting to note that there is a wrong spelling for "数量" (amount) - this should be "数辆" (some).

On Weibo, the extensive employment of vague discourse may be used for the purposes of objective assessment or descriptions, in an effort to avoid releasing incorrect information or to avoid misguiding the public when 
informing people about mass incidents. However, this writing style also undermines the authority and credibility of the government, since it fosters doubt among Weibo's netizens who want to know the whole truth about an incident, and may encourage lawbreakers to spread rumors. This post was re-posted over 1000 times and received over 500 comments; some of the commentators criticize the government of being incompetent because it did not release precise information as soon as possible. It can be inferred that vagueness, which is regarded as a traditional ideological discourse through which dominant groups try to influence the public, fails to work effectively in the digital age.

Moreover, the writer of the article employs evaluative discourse to some extent. Some expressions such as "煽动" (incitement) and "欧打" (hit) convey the government's negative attitude towards the "不法分子" (lawbreaker). In contrast, the writer uses expressions such as "保持克制" (show restraint) and "全力维护秩序" (try their best to keep everything in order) to cast positive judgments on the "民警" (police) and "协警" (assistant police). The narrative is that the lawbreakers are violent and dangerous, and the policemen are brave and righteous. The evaluative discourse in this case is the government's ideology that policemen and lawbreakers are at opposite ends of the moral spectrum.

E.g. 2: 近日里好多同学要毕业了, 找工作虽要紧, 却也不能忘防 范二字, 如今骗子越发多了, 杂乱信息必是车水马龙, 热闹得紧, 假 的更是, 若遇不法分子, 就不好了, 警叔多方考虑, 想出小秘諼, 私 心想着若给你阅读, 定可增强防范, 对你必是极好的。(Many guys will graduate in recent days. Although it is important to find a good job, you guys must be very cautious. Now there are more cheaters, and the misguiding information is difficult to distinguish. We "police uncle" want to share with you some good tips, and we believe it is typically good for you.)

In recent years, some special styles have appeared in government affairs articles on Weibo, among which the Yuanfang style and the Zhenhuan style are the most popular. They originate from popular TV series, and so are loved by the public. Under the Yuanfang style, a sentence starts with an event, which is followed by "元芳, 你怎么看" (Yuanfang, how do you think of it?). The answer is also a formatted text: "大人, 我觉得此事有蹊跷" ("Your honor, there must be a big secret behind this"). The Zhenhuan style also has its own symbolic characters: "真真是极好的" (it is typically good), and "倒也不负恩泽" (don't live up to their expectations).

The Zhenhuan style appears in example 2, in which undergraduates are to be cautious when hunting for a job. This microblog is widely accepted by young people, due to its unconventional or unorthodox expressions as well as its witty language, both of which satisfy the public's psychological needs. However, some people worry that an abundance of buzzwords on government affairs websites such as Weibo may undermine the authority of the government.

E.g. 3: \#XXX 回恐私生饭\# XXX 私生饭爆粗口骂 XXX, 当街互恐。 私生饭: 糊成这样你不知道吗? 跑这边来看你至于吗? XXX: 私生饭也 能叫粉丝吗? 私生饭: 你说什么, XXX, 我以后再也不来看你啦, 你 $* *$, 你有种过来说! 至于吗? (\#An idol responds to his celebrity stalker\# A celebrity stalker shouts to her idol on the street.
The celebrity stalker: Can you see you have flopped badly? I specially come here to see you. The idol: You guys are not my fans. The celebrity stalker: What? I will never go to see you. Just come here if you get guts!)

Classification is a linguistic ordering of the world (Fowler et al., 1972, p.210). The classification system in discourse refers to the choice of words used for names and descriptions of persons and events in a discourse. However, language is by no means an objective tool for classification. The labels that people attach to objects through language do not necessarily reflect the inherent features of the objects, for they are influenced by their level of cognition and thinking. Therefore, different views towards objects and experience will lead to different principles of classification.

This Weibo was produced by an influential We Media. In this case, the word "私生饭"(celebrity stalker) refers to some obsessive fans who make track for stars and disturb their normal life. This concept is originated from South Korea, which is called "Sasaeng fans". Since many idols go through severe invasions of privacy from these fervent supporters, " 私生饭"(celebrity stalker) are not welcomed by most of the stars and their rational followers. By using such classification of certain groups of people, Weibo writers build a negative image of the frantic fans.

In addition to the classification discussed above, the employment of emoticons and hashtags (with \#Topic\#) are also significant. Emoticons are important elements that are used to express people's feelings and attitudes via computermediated communication (Huffaker and Calvert, 2008). They can be used to strengthen people's emotions and support interpersonal connections (Zappavigna, 2012). In terms of the hashtags, Zhu (1996) states that one must "...judge whether there exists...coherence among paragraphs or sentences...if there is a topic [that forms] the center [of] the development of the discourse or article. If there is a certain topic and the discourse is devoted to the topic, then the discourse is coherent". Within online discourse, hashtags with \#Topic\# are used to define the key element within the events and make the topic clearer to the reader. People who hold a genuine interest in the issue (that is represented by the word beside the hashtag) could search through hashtags in order to find relevant information. This way, a connection between the writer and the public can be strengthened.

E.g. 4: 通往天台的路很长, 天台的风还很大。冷静下来想想, 毕 竟像阿根廷、德国、巴西这样的国家, 有可能你都还没去过。(There is a long distance between you and the large roof, let alone the strong wind there. Please calm down, and think twice. You may never go to Argentina, Germany and Brazil before. )

This Weibo was produced during the World Cup. "The large roof" is a joke among soccer fans, and it means that someone may commit suicide by jumping off the building if the team he bet on loses the match. The Weibo owner uses this "duanzi" (a representative of Chinese non-official or folklore discourse, which is created in reference to laughing stocks in people's lives) to warn the netizens to abide by the laws and control the emotions when they watch soccer matches. Despite the website being a dominant group on the 
Internet, the writer lowers Weibo's status to the same level as the public. By employing the discursive strategy of humor, the government could foster a close relationship with the common people.

\section{CONCLUSION}

In this paper, a CDA approach has been used to investigate the way in which the Chinese government takes advantage of the government affairs website, Weibo, to conduct discourse supervision on the reporting of some hot issues. Since van Dijk's mental model includes the concepts of the dominant group, ideology, power, and discourse, this was used as the theoretical framework in this paper. It was found that the government employs some common discursive strategies in both traditional ideological discourse and in online communication. For example, vagueness is still utilized in discourse on Weibo. However, sometimes this is not favored by the public, and probably does not enhance the government's image. Some new discursive strategies, such as the Zhenhuan style and Chinese rhetorical devices, are more acceptable among ordinary netizens. Therefore, it may be concluded that in the age of Web 2.0, as well as dominant groups using ideological discourse to gain and retain power (according to van Dijk's theory), this dominant group will use Weibo-enabled functions like hashtags, new language styles, intertextuality and rhetorical devices, in order to improve its image in a more subtle way. Ordinary people who are lacking in power and influence need to identify the strategies that dominant groups use in their discursive practices, so that they can better protect themselves and identify when dominant groups are using their power in an improper way.

\section{REFERENCES}

[1] Chin, G. (2014). Censorship of social media in China. Science, 345(6199), 886-888.

[2] Fairclough, N. (1992). Discourse and social change. Cambridge, UK ; Cambridge, MA: Polity Press.

[3] Fowler, R. (1979). Language and control. London ; Boston: Routledge \& K. Paul.

[4] Hodge, B., \& Kress, Gunther R. (1988). Social semiotics. Cambridge: Polity.

[5] Liu, Y., \& Zhou, Y. (2011). Social media in China: Rising Weibo in government. Digital Ecosystems and Technologies Conference (DEST), 2011 Proceedings of the 5th IEEE International Conference on, 213-219.

[6] Yin, L., \& Liu, X. (2014). A gesture of compliance: Media convergence in China. Media Culture and Society, 36(5), 561-577.

[7] Yinbin Liu, Yixia Zhou, \& Geng Liu. (2012). Chinese government use of social media: A case of Shanghai Weibo @ Shanghaicity. Digital Ecosystems Technologies (DEST), 2012 6th IEEE International Conference on, 1-5.

[8] Ong, J. (2013). China"s Sina Weibo grew 73\% in 2012, passing 500 million registered accounts.

[9] Retrieved from http://thenextweb.com/asia/2013/02/21/chinas-sinaweibo-grew-73-in-2012-passing-500-million-registered-accounts/

[10] Wodak, R., \& Meyer, Michael. (2009). Methods of critical discourse analysis (2nd ed., Introducing qualitative methods). London: Sage.

[11] Van Dijk, T. A.: "Critical Discourse Analysis ( second draft)".
[12] Retrieved from http: //www. mfsd. org /debate /vandijk. pdf. $1998 /$ $2012-9$.

[13] Van Dijk, T. A.: "Ideology and Discourse: A Multidisciplinary Introduction".

[14] Retrived from http: //www. discourses. org /Unpublished Articles/Ideology\%20and\%20discourse. pdf. $2000 / 2013-7-2$, pp. $44-60$

[15] Weber, I. (2010). Commodifying digital television in China: A sociolinguistic analysis of media discourse, technology deployment and control. New Media \& Society, 12(2), 289-308.

[16] Zappavigna, M. (2012). Discourse of Twitter and social media : How we use language to create affiliation on the web (Continuum discourse series). London: Continuum. 